\title{
Peningkatan Motivasi Dan Hasil Belajar Siswa Tentang Pesawat Sederhana Dengan Metode Demonstrasi
}

\section{Sri Wahyuningsih}

\author{
Guru IPA SMP N 3 Teras Boyolali \\ iik.trenggono@gmail.com
}

DOI: 10.23917/varidika.v32i1.11535

\begin{abstract}
Submission
Track:

Received:

15 March 2020

Final Revision:

15 April 2020

Available online:

31 June 2020

Corresponding

Author:

Sri Wahyuningsih

iik.trenggono@gmail.com

ABSTRAK

Tujuan penelitian ini adalah untuk meningkatkan motivasi dan hasil belajar siswa kelas VIII B SMP Negeri 3 Teras Tahun Pelajaran 2019/2020 pada materi Pesawat Sederhana. Penelitian Tindakan Kelas ini menggunakan dua siklus, setiap siklusnya terdiri atas perencanaan, tindakan, pengamatan, dan refleksi. Metode pengumpulan data yang digunakan adalah dokumentasi, observasi, dan tes tertulis. Untuk memperoleh data dan kejadian selama Tindakan Kelas yang dilakukan maka segala catatan kegiatan dan observasi yang dilakukan dikumpulkan dan diadministrasikan untuk kegiatan pelaporan. Berdasarkan analisis data, perbandingan prestasi belajar siswa pada pra siklus dan siklus I meningkat. Untuk nilai terendah meningkat dari 36 menjadi 48 atau meningkat sebesar 25\%. Dan nilai rerata meningkat cukup baik yaitu dari 58 menjadi 62 atau meningkat sebesar 5,88\%. Nilai tertinggi yang diperoleh siswa pada pra siklus 86 meningkat menjadi 98 atau meningkat sebesar 4,65\%. pada kondisi awal, nilai tertinggi yang diperoleh siswa adalah 86 berjumlah 2 anak, sedang pada siklus II (kondisi akhir) nilai tertinggi yang diperoleh siswa 100 berjumlah 3 anak. Nilai terendah pada kondisi awal sebesar 36 dan pada siklus II (kondisi akhir) sebesar 61 yang juga meningkat sebesar 45,8\%. Nilai rata-rata kelas meningkat signifikan dari 48 pada kondisi awal menjadi 68 pada siklus II (kondisi akhir) yaitu sebesar 14,7\%. Hal ini sudah memenuhi harapan untuk mencapai batas KKM (Kriteris Ketuntasan Minimal) sebesar 65. Berdasar analisis di atas, dapat disimpulkan bahwa penggunaan metode demonstrasi dapat meningkatkan motivasi dan hasil belajar siswa kelas VIII B SMP Negeri 3 Teras Tahun Pelajaran 2019/2020 pada materi Pesawat Sederhana.
\end{abstract}

Kata kunci : metode demonstrasi, motivasi belajar, hasil belajar, pesawat sederhana 


\section{PENDAHULUAN}

Siswa yang memiliki motivasi tinggi pasti juga akan aktif selama mengikuti proses pembelajaran (Depdiknas, 2007:1). Dalam proses pembelajaran guru harus menciptakan suasana sedemikian rupa sehingga siswa aktif bertanya, mempertanyakan, dan mengemukakan gagasan. Belajar merupakan suatu proses aktif dari si pembelajar dalam membangun pengetahuannya, bukan proses pasif yang hanya menerima kucuran ceramah guru tentang pengetahuan (Johnson, 2002). Menurut Cronbach (Suryabrata, 1984:231) menyatakan belajar yang sebaik-baiknya adalah dengan mengalami.

Setiap siswa memiliki motivasi belajar yang tidak sama. Salah satu tugas guru adalah menumbuhkan motivasi belajar pada diri siswa dengan cara menciptakan pembelajaran yang menarik dan bermakna bagi siswa. Motivasi yang tinggi merupakan hal penting dalam kelancaran pencapaian tujuan pembelajaran (Gunawan, 2019). Motivasi juga diartikan sebagai suatu perubahan energi di dalam diri pribadi seseorang yang ditandai dengan timbulnya afektif dan reaksi untuk mencapai tujuan ( Hamalik, 1992: 173).

Teori di atas banyak yang tidak sesuai dengan kenyataan di kelas, misalnya di SMP Negerii 3 Teras Boyolali. Motivasi dan hasil belajar siswa kelas VIII B SMP Negeri 3 Teras Tahun Pelajaran 2019/2020 pada materi Pesawat Sederhana masih rendah. Beberapa hal yang menunjukkan bahwa motivasi belajar rendah adalah sebagai berikut: (1) Siswa rata-rata diam pasif pada waktu proses pembelajaran berlangsung; (2) Pada saat diberi pertanyaan siswa masih kelihatan bingung; (3) Ketika diberikan soal, hanya beberapa siswa yang mampu mengerjakan dengan benar; (4) Ketika diskusi, siswa tidak berani aktif berperan sehingga kondisi diskusi pasif.

Hasil belajar siswa kelas VIII B SMP Negeri 3 Teras tahun pelajaran 2019/2020 juga masih rendah. Ketika diberikan ulangan harian (tes), nilai tertinggi yang diperoleh siswa adalah 86, nilai terendah 46, dan nilai rata-rata kelas 58. Hal ini masih jauh dari harapan untuk mencapai batas KKM (Kriteris Ketuntasan Minimal) sebesar 65. Hasil tersebut diperoleh karena peneliti belum menerapkan model pembelajaran dan metode pembelajaran secara efektif serta peneliti belum memanfaatkan berbagai sumber belajar yang dibutuhkan siswa.

Pada kondisi akhir setelah peneliti melakukan setiap tahap tindakan baik pada tindakan siklus I maupun siklus II yang direncanakan, diharapkan ada peningkatan terhadap proses belajar mengajar yang dapat dilihat dari hasil pengamatan terhadap keaktifan siswa selama proses pembelajaran. Prestasi belajar dari hasil ulangan harian untuk jumlah siswa tuntas, 
belum tuntas, nilai tertinggi, nilai terendah, rata-rata nilai pada mapel IPA materi Pesawat Sederhana

siswa kelas VIII B SMP Negeri 3 Teras Tahun Pelajaran 2019/2020 dengan menggunakan metode demonstrasi.

Pada kenyataan dilapangan bahwa kondisi proses belajar mengajar belum baik, hal ini dapat dilihat dari hasil pengamatan terhadap aktivitas siswa selama proses pembelajaran. Demikian juga nilai prestasi belajar siswa untuk hasil ulangan harian pada jumlah siswa tuntas, belum tuntas, nilai tertinggi, nilai terendah, dan rata-rata nilai. pada mapel IPA oleh materi Pesawat Sederhana siswa kelas VIII B SMP Negeri 3 Teras Tahun Pelajaran 2019/2020 masih rendah.

Kenyataan yang dijumpai guru yaitu motivasi dan prestasi belajar siswa kelas VIII B SMP Negeri 3 Teras Tahun Pelajaran 2019/2020 jauh dari harapan dan tuntutan dalam kurikulum. Peneliti berkeyakinan hal ini disebabkan oleh rendahnya kemampuan siswa dalam memahami materi Pesawat Sedehana. Namun peneliti yakin apabila guru mampu mengaplikasikan teknik-teknik yang menarik dan cara-cara yang tepat dan tidak membosankan dalam pembelajaran, tujuan pembelajaran itu akan tercapai. Masalah belum baiknya prestasi belajar siswa dalam hal ini dapat dilihat dari hasil ulangan harian pada jumlah siswa tuntas, belum tuntas, nilai tertinggi, nilai terendah, dan rata-rata nilai, pada mapel IPA materi Pesawat Sederhana pada siswa kelas VIII B SMP Negeri 3 Teras Tahun Pelajaran 2019/2020 perlu dipecahkan dengan menggunakan metode demonstrasi untuk meningkatkan motivasi dan hasil belajar siswa secara signifikan. Selanjutnya, masalah yang dikaji adalah 1) Apakah melalui penggunaan metode demonstrasi dapat meningkatkan motivasi belajar IPA konsep Pesawat Sederhana bagi siswa kelas VIII B SMP Negeri 3 Teras pada semester 1 tahun pelajaran 2019/2020; 2) Apakah melalui penggunaan metode demonstrasi dapat meningkatkan hasil belajar IPA konsep Pesawat Sederhana bagi siswa kelas VIII B SMP Negeri 3 Teras pada semester 1 tahun pelajaran 2019/2020; 3) Apakah melalui penggunaan metode demonstrasi dapat meningkatkan motivasi dan hasil belajar IPA konsep Pesawat Sederhana bagi siswa kelas VIII B SMP Negeri 3 Teras pada semester 1tahun pelajaran 2019/2020?. 


\section{METODE PENELITIAN}

Penelitian ini secara keseluruhan dilaksanakan selama enam bulan, yakni bulan Juli 2019 hingga Desember 2019. Pada bulan Juli 2019 digunakan untuk persiapan. Bulan Agustus dan September 2019 dilakukan tindakan dengan aplikasi Siklus I dan II. Bulan Oktober dan November 2019 digunakan untuk pengumpulan dan analisis data, dan bulan Desember 2019 penyusunan laporan.

Tempat penelitian diambil di tempat dimana peneliti mengajar yaitu di kelas VIII B SMP Negeri 3 Teras Boyolali. Subjek penelitian ini yaitu siswa kelas VIII B SMP Negeri 3 Teras Boyolali yang berjumlah 30 siswa yang terdiri dari siswa putra16, dan siswa putri 14 .

Teknik pengumpulan data untuk memperoleh data awal peneliti menggunakan teknik dokumentasi. Teknik dokumentasi dilakukan untuk memperoleh dan menganalisis data secara kritis terhadap kondisi siswa dan juga hasil belajar siswa. Metode ini digunakan untuk mengumpulkan berbagai informasi dari bahan-bahan dokumenter, misalnya catatan harian personal siswa, buku daftar nilai, dan juga buku pribadi siswa. Untuk pengumpulan data pada siklus I dan siklus II dilakukan teknik observasi yaitu untuk memperoleh data tentang aktivitas belajar siswa. memperoleh data prestasi belajar siswa pada siklus I dan siklus II dilakukan tes tertulis. Tes tertulis merupakan ulangan harian yang diberikan setiap KD. Nilai yang diperoleh siswa merupakan sumber data prestasi belajar siswa. Tes Tertulis untuk ulangan harian pada tindakan prasiklus, ulangan harian siklus I dan ulangan harian siklus II dari Standar Kompetensi Pesawat Sederhana.

Validasi data yang digunakan adalah validasi isi (content validity). Validasi data untuk aktivitas belajar siswa diperlukan adanya triangulasi sumber data. Menurut Moleong (2007: 330) Triangulasi adalah teknik pemeriksaan keabsahan data yang memanfaatkan sesuatu yang lain di luar data itu untuk keperluan pengecekan atau sebagai pembanding terhadap data itu. Untuk triangulasi data maka sumber data yang pertama yaitu peneliti, sumber data yang kedua adalah siswa, dan yang ketiga adalah teman sejawat, atau wali kelas, atau guru bimbingan konseling. Dalam penelitian tindakan kelas triangulasi dinamakan kolaborasi dengan teman sejawat. Kolaborasi ini berfungsi untuk validasi data. Jika tidak ada teman sejawat dapat juga digunakan triangulasi metode. Analisis data yang digunakan adalah analisis deskriptif komparatif yang diikuti dengan refleksi. Yaitu dengan membandingkan hasil prestasi belajar siswa dari hasil kondisi awal (prasiklus) dengan hasil belajar siswa setelah tindakan siklus I dan hasil prestasi belajar setelah tindakan siklus II, dari hasil pembandingan tersebut dilakukan 
refleksi dengan menarik kesimpulan untuk memperoleh data ada tidaknya peningkatan prestasi hasil belajar siswa, untuk selanjutnya menentukan tindak lanjut (Hamidi, 2004).

Penelitian ini menggunakan metode Penelitian Tindakan Kelas dngan menggunakan pendekatan proses yang berkesinambungan yang direncanakan dalam dua siklus. Dalam setiap siklusnya, meliputi empat tahap yaitu tahap perencanaan, pelaksanaan, observasi dan tahap refleksi.

\section{HASIL DAN PEMBAHASAN}

\section{Deskripsi Prasiklus (Tindakan Awal)}

\section{Motivasi Belajar IPA}

Motivasi belajar siswa di kelas pada waktu proses pembelajaran IPA konsep Pesawat Sederhana sangat kurang. Hal ini dapat dilihat beberapa siswa tampak bertopang dagu dan melamun, mengantuk, yang menandakan kebosanan, tidak bergairah, kurang memperhatikan pelajaran, apatis, dan tidak berkonsentrasi. Ada juga siswa yang bercerita sendiri dengan temannya sambil tertawa. Guru merupakan satu-satunya sumber belajar. Guru mengajar dengan metode ceramah, tanya jawab, mengerjakan latihan soal. Tetapi sulit membawa siswa terlibat aktif dalam pembelajaran. Beberapa siswa saja yang mau memperhatikan pelajaran dengan sungguh-sungguh, aktif belajar, memiliki motivasi tinggi, dan tampak juga mencatat hal-hal penting yang dijelaskan guru.

\section{Hasil Belajar IPA}

Hasil belajar siswa kelas VIII B SMP Negeri 3 Teras tahun pelajaran 2019/2020 juga masih rendah. Ketika diberikan ulangan harian (tes), nilai tertinggi yang diperoleh siswa adalah 86, nilai terendah 36 , dan nilai rata-rata kelas 58. Hal ini masih jauh dari harapan untuk mencapai batas KKM (Kriteris Ketuntasan Minimal) sebesar 65.

\section{Deskripsi Hasil Siklus I}

\section{Hasil Pengamatan Motivasi Belajar IPA materi Pesawat Sederhana}

Pada pembelajaran siklus I tentang Pesawat Sederhana dengan menggunakan metode demonstrasi, motivasi belajar siswa meningkat. Ada siswa yang mengembangkan konsep dengan mencari contoh-contoh yang ada di lingkungannya. Motivasi belajar siswa juga dapat 
dilihat meningkatnya keaktifan siswa dalam mengikuti pembelajaran, menjawab pertanyaan, atau bertanya tentang hal-hal yang belum dimengerti.

\section{Hasil Pengamatan Prestasi Belajar IPA Materi Pesawat Sederhana}

Setelah diberikan proses pembelajaran pada siklus I dengan menggunakan metode demonstrasi konsep Pesawat Sederhana pada siswa kelas VIII B SMP Negeri 3 Teras tahun pelajaran 2019/2020 agak meningkat. Ketika diberikan tes tertulis, nilai tertinggi yang diperoleh siswa adalah 98, meningkat dari kondisi awal dimana nilai tertinggi sebesar 86 . Nilai ini tentu saja masih belum maksimal karena belum mencapai angka 100. Untuk nilai terendah meningkat dari 36 menjadi 48 atau meningkat sebesar 25\%. Nilai rerata meningkat cukup baik yaitu dari 58 menjadi 62 atau meningkat sebesar 5,88\%. Nilai tertinggi yang diperoleh siswa pada pra siklus 86 meningkat menadi 98 atau meningkat sebesar 13,95\%. Nilai rerata ini masih berada dibawah KKM sehingga masih perlu ditingkatkan lagi. Hasil belajar siswa dapat dilihat pada tabel berikut.

Tabel 1.

Nilai tes tertulis siswa siklus I

\begin{tabular}{|c|l|c|}
\hline No & \multicolumn{1}{|c|}{ Uraian } & Nilai tes \\
\hline 01 & Nilai terendah & 48 \\
02 & Nilai tertinggi & 98 \\
03 & Nilai rerata & 62 \\
\hline
\end{tabular}

Nilai tes tertulis pada siklus I dapat dilihat pada gambar diagram berikut.

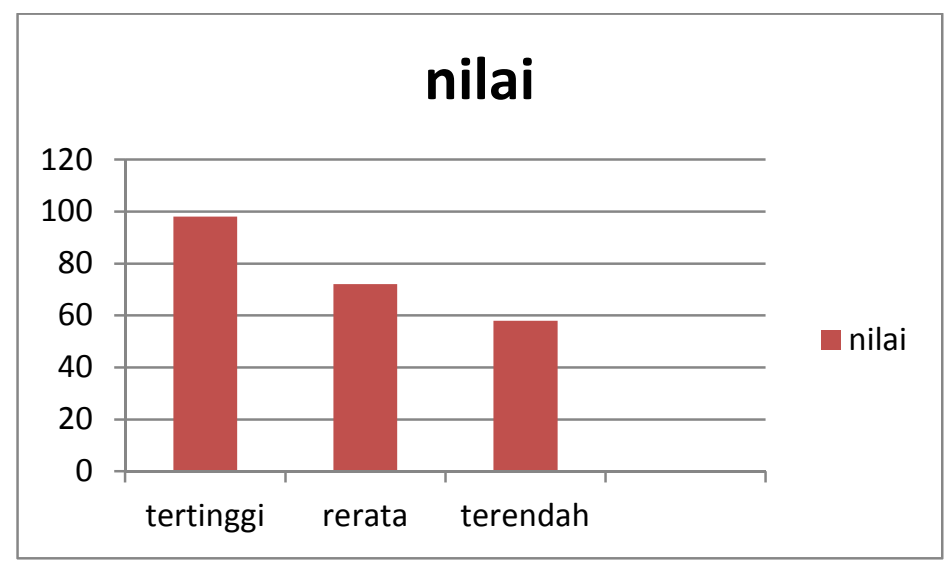

Gambar 1

Diagram batang nilai tes siklus I 


\section{Deskripsi Hasil Siklus II}

\section{Hasil Pengamatan Motivasi Belajar IPA materi Pesawat Sederhana}

Hasil Pengamatan Motivasi Belajar IPA konsep Pesawat Sederhana

Pada pembelajaran siklus II tentang Pesawat Sederhana dengan menggunakan metode demonstrasi dan diskusi dalam kelompok kecil, motivasi belajar siswa meningkat. Siswa yang berani bertanya bertambah jumlahnya lebih dari $50 \%$. Siswa tidak lagi takut dan malu untuk bertanya dan mengeluarkan pendapat. Siswa belajar dengan rasa ingin tahu yang besar membuat mereka sangat antusias dan bekerja dengan bersemangat.

\section{Hasil Pengamatan Prestasi Belajar IPA Materi Pesawat Sederhana}

Hasil belajar IPA konsep Pesawat Sederhana setelah diberikan proses pembelajaran pada siklus II pada siswa kelas VIII B SMP Negeri 3 Teras tahun pelajaran 2019/2020 meningkat. Ketika diberikan ulangan harian (tes), nilai tertinggi yang diperoleh siswa adalah 100 meningkat dari siklus I yang mana nilai tertinggi yang diperoleh siswa 98 atau meningkat sebesar 2,04\%. Nilai terendah 48 yang juga meningkat dari pada siklus I sebesar 61 atau meningkat sebesar 12,07\%. Nilai rata-rata kelas meningkat signifikan dari 62 menjadi 68 atau meningkat sebesar 8,33\%. Hal ini sudah memenuhi harapan untuk mencapai batas KKM (Kriteris Ketuntasan Minimal) sebesar 65 bahkan melampaui yang ditargetkan. Hasil belajar dari siswa dapat dilihat pada tabel berikut.

Tabel 2

Nilai ulangan harian siswa siklus II

\begin{tabular}{|c|l|c|}
\hline No & \multicolumn{1}{|c|}{ Uraian } & Nilai ulangan harian \\
\hline 01 & Nilai terendah & 61 \\
02 & Nilai tertinggi & 100 \\
03 & Nilai rerata & 68 \\
\hline
\end{tabular}

Nilai ulangan harian pada siklus II juga dapat dilihat pada gambar diagram berikut. 


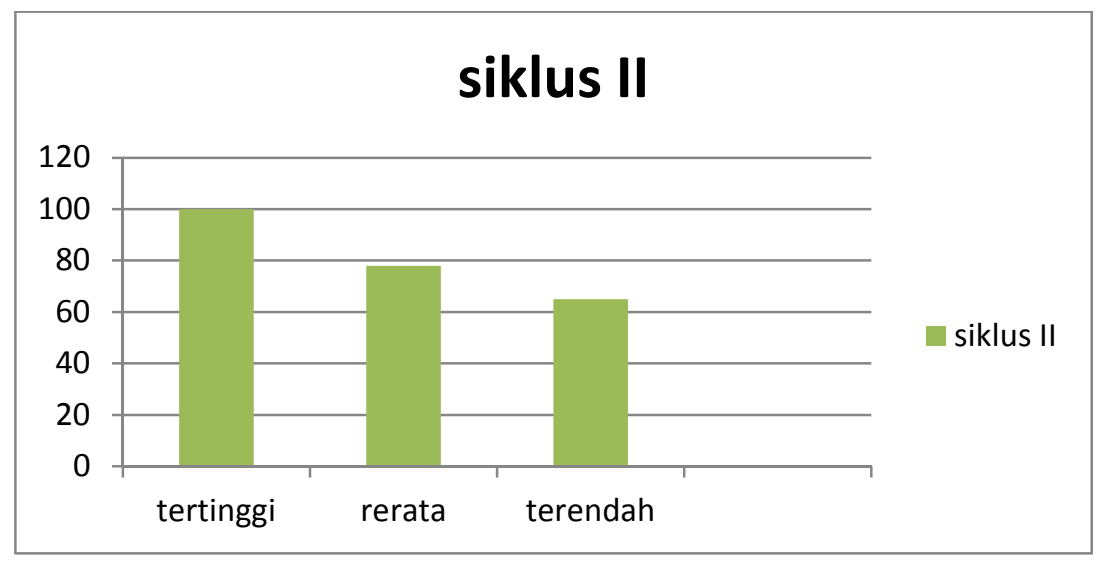

Gambar 2.

Diagram batang nilai tes siklus II

\section{Pembahasan/Diskusi}

Motivasi belajar siswa konsep Pesawat Sederhana bagi siswa kelas VIII B SMP Negeri 3 Teras pada semester 1 tahun pelajaran 2019/2020 pada kondisi awal dengan kondisi akhir dapat dilihat pada tabel berikut.

Tabel 3

Motivasi belajar siswa konsep Pesawat Sederhana pada kondisi awal dengan kondisi akhir

\begin{tabular}{|l|l|l|l|l|}
\hline No & \multicolumn{1}{|c|}{ Kriteria } & \multicolumn{1}{|c|}{ Pra siklus } & \multicolumn{1}{|c|}{ Siklus I } & \multicolumn{1}{|c|}{ Siklus II } \\
\hline 1 & Rendah & $10 \%$ & $6,67 \%$ & $0 \%$ \\
\hline 2 & Sedang & $46,67 \%$ & $36,67 \%$ & $20 \%$ \\
\hline 3 & Tinggi & $26,67 \%$ & $26,67 \%$ & $33,33 \%$ \\
\hline 4 & Sangat tinggi & $16,67 \%$ & $30 \%$ & $46,67 \%$ \\
\hline
\end{tabular}

Simpulan dari kondisi awal dengan kondisi akhir yaitu melalui pemanfaatan metode demonstrasi dapat meningkatkan motivasi belajar IPA konsep Pesawat Sederhana bagi siswa kelas VIII B SMP Negeri 3 Teras pada semester 1 tahun pelajaran 2019/2020. Motivasi belajar siswa pada kondisi awal dan kondisi akhir pada konsep Pesawat Sederhana mengalami peningkatan.

\section{Hasil Pengamatan Hasil Belajar IPA konsep Pesawat Sederhana}

Hasil belajar IPA konsep Pesawat Sederhana setelah diberikan proses pembelajaran pada siklus II pada siswa kelas VIII B SMP Negeri 3 Teras tahun pelajaran 2019/2020 meningkat. Ketika diberikan ulangan harian (tes), nilai tertinggi yang diperoleh siswa adalah 100 meningkat dari siklus I yang mana nilai tertinggi yang diperoleh siswa 98 atau meningkat sebesar 2,04\%. Nilai terendah 61 yang juga meningkat dari pada siklus I sebesar 48 atau 
meningkat sebesar 12,07\%. Nilai rata-rata kelas meningkat signifikan dari 62 menjadi 68 atau meningkat sebesar $8,33 \%$. Hal ini sudah memenuhi harapan untuk mencapai batas KKM (Kriteris Ketuntasan Minimal) sebesar 65 bahkan melampaui yang ditargetkan. Hasil belajar dari siswa dapat dilihat pada tabel berikut.

Tabel 4.

Nilai ulangan harian siswa siklus II

\begin{tabular}{|l|l|c|}
\hline No & \multicolumn{1}{|c|}{ Uraian } & Nilai ulangan harian \\
\hline 01 & Nilai terendah & 61 \\
02 & Nilai tertinggi & 100 \\
03 & Nilai rerata & 68 \\
\hline
\end{tabular}

Nilai ulangan harian pada siklus II juga dapat dilihat pada gambar diagram berikut.

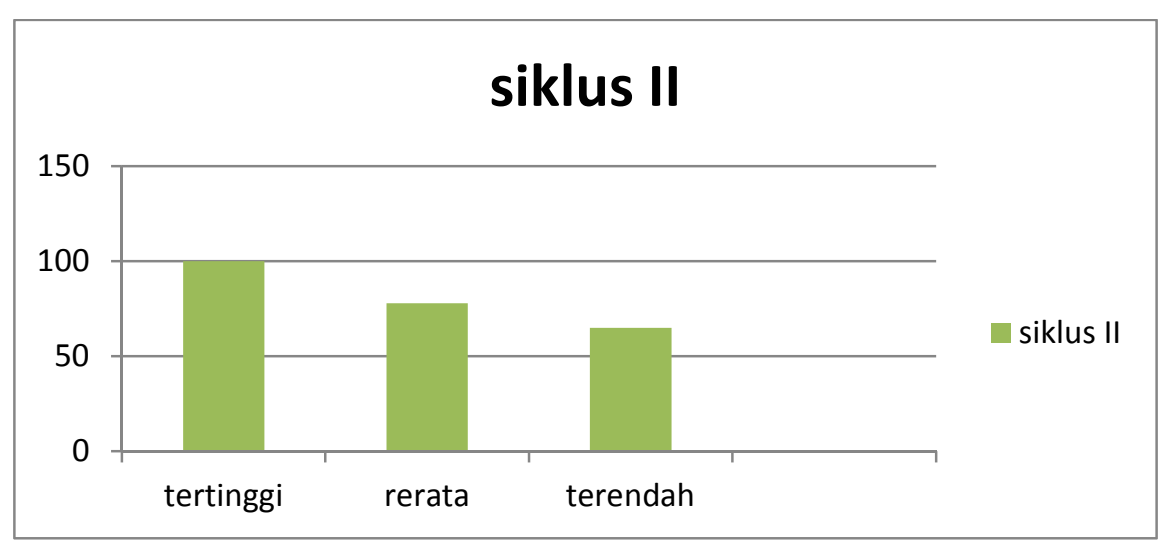

Gambar 3.

Diagram batang nilai tes siklus II

\section{Pembahasan/Diskusi}

Motivasi belajar siswa konsep Pesawat Sederhana bagi siswa kelas VIII B SMP Negeri 3 Teras pada semester 1 tahun pelajaran 2019/2020 pada kondisi awal dengan kondisi akhir meningkat lebih baik. Simpulan dari kondisi awal dengan kondisi akhir yaitu melalui pemanfaatan metode demonstrasi dapat meningkatkan hasil belajar IPA konsep Pesawat Sederhana bagi siswa kelas VIII B SMP Negeri 3 Teras tahun pelajaran 2019/2020. Hasil belajar dari siswa pada kondisi awal dengan kondisi akhir dapat dilihat pada tabel berikut. 
Tabel 5. Nilai ulangan harian siswa kondisi awal dan kondisi akhir

\begin{tabular}{|c|l|c|c|}
\hline No & \multicolumn{1}{|c|}{ Uraian } & Nilai UH kondisi awal & Nilai UH kondisi akhir \\
\hline 01 & Nilai terendah & 36 & 61 \\
02 & Nilai tertinggi & 86 & 100 \\
03 & Nilai rerata & 58 & 68 \\
\hline
\end{tabular}

Nilai ulangan harian pada kondisi awal dan kondisi akhir juga dapat dilihat pada gambar diagram berikut.

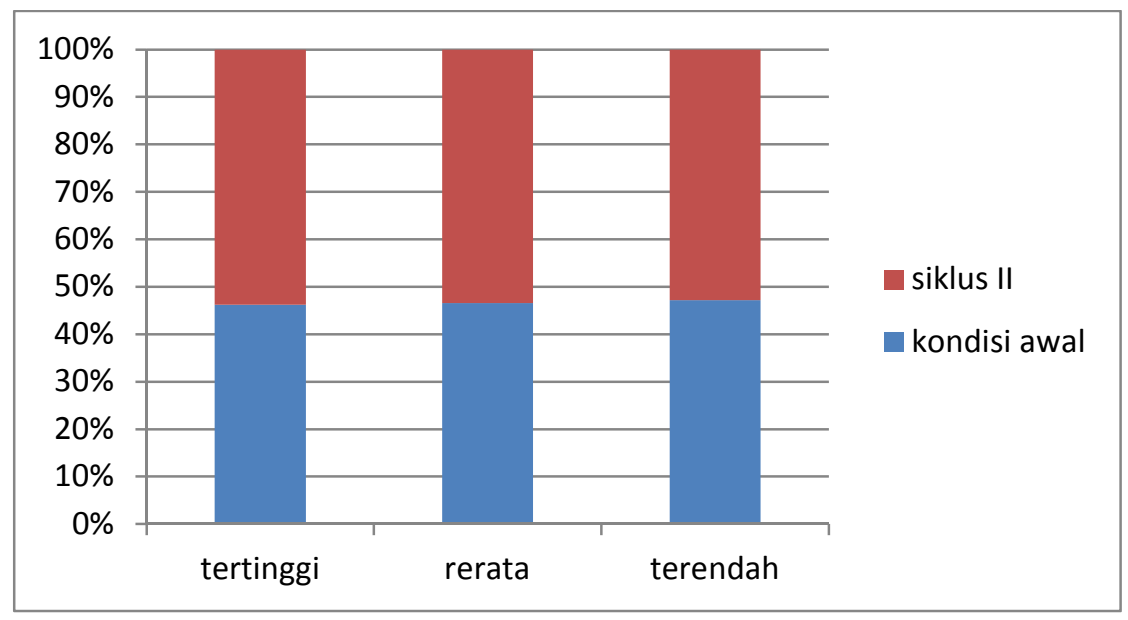

\section{Gambar 4}

Diagram batang nilai ulangan harian kondisi awal dan siklus II

\section{Hasil Tindakan}

1. Melalui pemanfaatan metode demonstrasi dapat meningkatkan motivasi belajar IPA konsep Pesawat Sederhana bagi siswa kelas VIII B SMP Negeri 3 Teras tahun pelajaran 2019/2020. Pada kondisi awal motivasi belajar siswa rendah meningkat pada kondisi akhir yaitu motivasi belajar siswa tinggi.

2. Melalui pemanfaatan metode demonstrasi dapat meningkatkan hasil belajar IPA konsep Pesawat Sederhana bagi siswa kelas VIII B SMP Negeri 3 Teras tahun pelajaran 2019/2020. Pada kondisi awal hasil belajar IPA konsep Pesawat Sederhana nilai rata-rata yang diperoleh siswa sebesar 58 meningkat pada kondisi akhir nilai rata-rata sebesar 68 meningkat sebesar $14,7 \%$.

Melalui pemanfaatan metode demonstrasi dapat meningkatkan motivasi dan hasil belajar IPA konsep Pesawat Sederhana bagi siswa kelas VIII B SMP Negeri 3 Teras tahun pelajaran $2019 / 2020$. 


\section{SIMPULAN}

Berdasarkan hipotesis melalui pemanfaatan metode demonstrasi dapat meningkatkan motivasi dan hasil belajar IPA pada konsep Pesawat Sederhana bagi siswa kelas VIII B SMP Negeri 3 Teras tahunpelajaran 2019/2020. Menurut empirik melalui pemanfaatan metode demonstrasi dapat meningkatkan motivasidan hasil belajar IPA pada konsep Pesawat Sederhana bagi siswa kelas VIII B SMP Negeri 3 Teras.

\section{Implikasi}

Hasil penelitian menunjukkan bahwa dengan pemanfaatan metode demonstrasi dapat meningkatkan motivasidan hasil belajar IPA pada konsep Pesawat Sederhana, maka pada waktu mengajar IPA konsep Pesawat Sederhana dapat menggunakan metode demonstrasi.

\section{Saran}

Saran kepada guru yaitu 1) Menambah wawasan pemilihan media pembelajaran sesuai dengan konsep yang diajarkan; 2) Dapat menciptakan situasi pembelajaran yang efektif dan efisien; 3) Guru berupaya untuk mengatasi pembelajaran yang konvensional, dan pada akhirnya dapat meningkatkan mutu proses pembelajaran di kelas; 4) Dapat dijadikan acuan bagi guru lain untuk mengadakan penelitian lebih lanjut.

\section{REFERENSI}

Depdiknas, 2003. Panduan Pengembangan Pembelajaran IPA TerpaduSMP/MTs. Jakarta: Pusat Kurikulum, Balitbabg Depdiknas.

Gunawan, Helmi. 2019. Improving Student'Motivation in Reading Comprehension Using Reciprocal Teaching. Jurnal Varidika. Vol.31 No .2 FKIP-UMS.

Hamalik, Oemar. 2002. Psikologi Belajar dan Mengajar, Bandung: Sinar Baru Algesindo. Hamidi, 2004. Metode Penelitian Kualitatif. Malang: UMM Press.

Johnson. Deborah Schaff. Quantum learning: Leadership for learning organizations. Futurics. St. Paul: 2002. Vol. 26, Iss. 3/4; pg. 89, 4 pgs. http://proquest.umi.com/pqdweb?did=274325541\&sid=2\&Fmt=3\&clien. $\quad$ accessed 10.56. 15 Januari 2008

Majid, Abdul. 2005. Perencanaan Pembelajaran. Bandung: PT. Remaja Rosdakarya.

Moleong J. Lexy. 2007. Metodologi Penelitian Kualitatif. Bandung: P.T. Remaja Rosdakarya. Sri Anifah.2010. Media Pembelajaran. Surakarta, Yuma Pustaka bekerjasama dengan FKIP UNS.

Sumadi Suryabrata, 1998. Psikologi Pendidikan, Jakarta: PT. Raja Grafindo Persada. Syah Muhibbin. 2003. Psikologi Belajar, Jakarta: Raja Grafindo Persada.

Trianto. 2010. Mengembangkan Model Pembelajaran Tematik, Jakarta: PT. Prestasi Pustakarya. 